\title{
(НЕ)ВРЕМЯ ВЗРОСЛЕТЬ: КАК МЕНЯЕТСЯ ВОЗРАСТ НАСТУПЛЕНИЯ ДЕБЮТНЫХ БИОГРАФИЧЕСКИХ СОБЫТИЙ У РОсСИЯн
}

\author{
ЕКАТЕРИНА МИТРОФАНОВА
}

\begin{abstract}
Бытует мнение, что нынешняя молодежь не только не торопится взрослеть, но и вообще отказывается обретать важные биографические события, которые как-то ограничивают их свободу и предполагают приверженность своему выбору (commitment). Чтобы узнать, так ли это, мы изучили возрастьл наступления шести дебютных событий жизненного пути: получение профессионального образования, первое трудоустройство, первое отделение от родителей, первое партнерство (незарегистрированные отношения с совместным проживанием), первый брак, рождение первого ребенка.
\end{abstract}

Mbl сопоставили поведение шести поколений россиян, родившихся между 1930 и 1986 годами. Выборка составила 5451 человека из панельной части обследования «Родители и дети, мужчины и женшчины в семье и обществе» (РиДМиЖ) по состоянию на 2011 г. Мы не только изучили медианные возрасты наступления событий и наглядно представили их на сетке Лексиса, но также оценили шансы обретения стартовых событий при помощи регрессий Кокса (event history analysis).

Было выявлено, что серьезного откладывания или отказа от социоэкономических событий не происходит: трудоустройство и отделение от родителей минимально меняют свою позицию 6 расписаниях жизни молодых поколений. Возраст завершения обучения отодвинулся на более поздний срок, но это связано с существенным ростом числа получающих профессиональное образование разных уровней. Возраст вступления в первое партнерство в молодых поколениях снизился до исторического минимума, став самым ранним из трех демографических событий в жизни современной молодежи. Другие два демографических события - первые браки и деторождения-действительно, откладываются молодыми поколениями, особенно мужчинами. То есть молодежь не саботирует взросление, но дебютирует в разных сферах жизни сообразно своим жизненным расписаниям и в свое время.

Ключевые слова: взросление, поколения, Россия, возраст, стартовые события жизненного пути, демографические события, брак, партнерство, деторождение, образование, работа, отделение от родителей, анализ наступления событий, сетка Лексиса.

\section{ВВЕДЕНИЕ}

Недавно Госдумой РФ был принят закон, сдвигающий верхнюю границу категории «молодежь» с 30 до 35 лет $^{1}$ (Замахина 2020), а два года назад был повышен возраст выхода на пенсию ${ }^{2}$.

ЕКАТЕРИНА СЕРГЕЕВНА МИТРОФАНОВА (emitrofanova@hse.ru), НАЦИОНАЛЬНЫЙ ИССЛЕДОВАТЕЛЬСКИЙ УНИВЕРСИТЕТ «ВЫСШАЯ ШКОЛА ЭКОНОМИКИ», РОССИЙСКАЯ АКАДЕМИЯ НАРОДНОГО ХОЗЯЙСТВА И ГОСУДАРСТВЕННОЙ СЛУЖБЫ ПРИ ПРЕЗИДЕНТЕ РОССИЙСКОЙ ФЕДЕРАЦИИ, РОССИЯ.

ИССЛЕДОВАНИЕ РЕАЛИЗОВАНО ПРИ ПОДДЕРЖКЕ ФАКУЛЬТЕТА СОЦИАЛЬНЫХ НАУК, НАЦИОНАЛЬНЫЙ ИССЛЕДОВАТЕЛЬСКИЙ УНИВЕРСИТЕТ «ВЫСШАЯ ШКОЛА ЭКОНОМИКИ».

СТАТЬЯ ПОСТУПИЛА В РЕДАКЦИЮ В НОЯБРЕ 2020 Г.

1 Замахина Т. (2020, декабрь 23). Госдума повысила возраст молодежи до 35 лет. Российская газета, 291(8345). URL: https://rg.ru/2020/12/23/vozrast-molodezhi-povysili-do-35-let-vkliuchitelno.html

2 Ф3 №350. (2018). Федеральный закон «О внесении изменений в отдельные законодательные акты Российской Федерации по вопросам назначения и выплаты пенсий» от 03.10 .2018 N 350 -Ф3. http://www.consultant.ru/document/cons_doc_LAW_308156/ 
Пересмотр юридически закрепленных границ наступления разных этапов жизни является откликом государства на изменения в организации жизни, которые проявляются настолько заметно и встречаются так повсеместно, что уже требуют фиксации на законодательном уровне.

За счет чего происходят передвижки границ разных этапов жизни? Это происходит из-за увеличения продолжительности жизни, в том числе здоровой. За последние полтора века перспектива прожить в среднем 30-40 лет сменилась перспективой в 70-80 лет, что стало расширять горизонты планирования людей и привело к «инфляции» возраста (Shoven, Goda 2011). В этих условиях отодвигание возрастов наступления ключевых событий жизни стало естественной реакцией людей. Расписания человеческой жизни стали трансформироваться, т.к. ненарушаемых социальных дедлайнов остается все меньше, а возможностей настройки календаря своих жизненных событий становится все больше (Giddens 1994; Heinz, Marshall 2003; Huinink 2013).

В условиях все более продолжительной жизни взросление, которое в традиционных обществах представляло регламентированный ритуал, событие, обряд инициации (Ремшмидт 1994), превращается в многоступенчатый процесс, полноценный и исторически новый этап жизненного пути. На этом этапе происходит наиболее высокая концентрация значимых событий, меняющих социальный статус индивида и устройство его жизни (Billari, Liefbroer 2007; Rindfuss 1991). К числу важных стартовых событий жизни, маркирующих вхождение во взрослую жизнь, демографы чаще всего относят завершение получения образования, выход на рынок труда, покидание родительского дома, первую интимную близость, первое партнерство (или незарегистрированные отношения, сожительство), первый брак, рождение первого ребенка. Хотя эти маркеры не являются универсальными и постоянно ставятся под сомнение и переосмысляются (Benjamin, Crymble 2017; Gabriel 2013; Gauthier 2007; Horowitz, Bromnick 2007; Lowe et al. 2013; Raveaud 2010; Vleioras, Mantziou 2018), это то, что мы имеем сегодня как консенсус, достигнутый в ходе множества дискуссий и проведения международных обследований (Billari et al. 2005; Buchmann 1989; Liefbroer 1999; Vikat et al. 2007).

Данное исследование продолжает наше изучение стартовых событий жизни в сопоставлении друг с другом и в разрезе гендерной и поколенческой принадлежности респондентов. Если в одной из предыдущих работ (Митрофанова 2019) мы описывали переход во взрослую жизнь как единый процесс, то в этой сфокусируемся на тайминге наступления отдельных событий. Мы проанализируем возрастные профили наступления событий как в статике (медианные возрасты), так и в динамике (повозрастные кумулятивные доли), а регрессионное моделирование (регрессии Кокса) позволит выявить факторы, сопутствующие тем или иным стратегиям.

Данная статья структурирована следующим образом: первый раздел посвящен анализу закономерностей трансформаций тайминга наступления социоэкономических и демографических событий, а второй раздел - анализу эмпирических данных на базе обследования «Родители и дети, мужчины и женщины в семье и обществе» (РиДМиЖ 2011 г.). 


\section{ОБЗОР ИССЛЕДОВАНИЙ И ГИПОТЕЗЫ}

Обновление календарей наступления ключевых событий жизни в западных странах началось с конца 1960-х годов и было частью более общего модернизационного процесса, маркированного известными молодежными протестами того времени (условно «революцией 1968 года» ${ }^{3}$ ), когда молодежи удалось добиться пересмотра законов об образовании, контрацепции, начать гендерную и сексуальную революцию. Второй демографический переход в этих странах происходил неравномерно и не одновременно; в России модернизация началась почти на тридцать лет позже - с распадом советского режима (Вишневский 2006; Puur et al. 2012). Трансформации, произошедшие в экономической, социальной и политической сферах жизни в 1990-е годы, отразились на особенностях наступления демографических и социоэкономических событий жизненного пути (Беляева 2004; Захаров 2009; Здравомыслова, Шурыгина 2001).

Отмена рестриктивных социоэкономических мер ${ }^{4}$ государственной политики создала предпосылки для наступления соџиоэкономических событий в более произвольном порядке и в более широких возрастных границах. Современная молодежь перестает следовать единым моделям поведения и демонстрирует все более вариативные сценарии наступления социоэкономических событий (Митрофанова, Артамонова 2015; Espy IV, Mitrofanova 2017; Mitrofanova 2016). В сфере образования заметна тенденция увеличения периода обучения, а в сфере занятости - сокращение доли занятых среди молодежи (Гимпельсон, Зудина 2017; Константиновский 2008: 283). Отделение от родителей среди молодых российских поколений происходит в более поздних возрастах, чем раньше (Долгова, Митрофанова 2015), что совпадает с результатами зарубежных исследователей (Billari, Liefbroer 2010; Corijn, Klijzing 2001: 15).

В демографической сфере также заметны подвижки в тайминге наступления стартовых событий. До октябрьской революции брачность и рождаемость россиян были ранними и универсальными. В 1897 г. в России 47\% женщин вступало в брак до 21 года (Тольц 1977), в возрасте 20-24 года в браке состояло 64,3\%. Подобная тенденция ранней брачности сохранялась до 1930-х годов, но была прервана историческими событиями, потребовавшими милитаризации экономики, мобилизации всего общества, в том числе изменения законов о воинской службе, занятости, образовании и др. В 1939 г. до 21 -летия в брак вступало всего $29 \%$ девушек. Затем нормы ранней и всеобщей брачности и рождаемости восстановились по мере нормализации брачного рынка и послевоенного усиления пронаталистской идеологии.

В 1970-1980-х годах возрастная модель заключения браков не сильно отличалась от той, что наблюдалась в России в конце XIX - начале XX века (Вишневский, Тольц 1988;

\footnotetext{
${ }^{3}$ Максимального накала протестные движения молодежи - противостояния на баррикадах в Латинском квартале Парижа - достигают именно в 1968 г. В то же время социальные протесты во всех формах (мирных и совсем не мирных) начались за несколько лет до 1968 г. и продолжались в 1969 г. и даже позднее не только в Париже, но и в Токио, Западном Берлине, Турине и Риме, Мадриде и Барселоне, Афинах, в Калифорнийском университете в Беркли и в других городах с высокой концентрацией учащейся молодежи.

${ }^{4}$ Под рестриктивными мерами подразумеваются те меры, которые ограничивали свободу выбора жизненной траектории. Например, обязательные отработки по распределению (до 1991 г.), невозможность уволиться или сменить работодателя (до 1956 г.), закон о тунеядстве (до 1991 г.) и др.
} 
Дарский, Ильина 1990; Захаров 2006; Вишневский, Кон 1979). Связка между сексуальным, матримониальным и репродуктивным поведением была очень сильной. Первые изменения стали намечаться с либерализацией сексуальной морали в 1970-е годы (Кон 1997; Голод 2005; Денисенко, Далла Зуанна 2001). Но эта либерализация сдерживалась, во-первых, общественно-политическим дискурсом (Арутюнян 1997; Здравомыслова, Темкина 2004; 2008), а во-вторых, отсутствием эффективной контрацепции (Тольц 1974; Троицкая и др. 2010; Popov et al. 1993).

Ситуация стала резко меняться после слома политической и экономической системы в 1991 году (Вишневский 2006: 249; Кон 2010; Семья и рождаемость... 2010: 14-15; Blum et al. 2009). К началу 1990-х годов в России возраст сексуального дебюта, вступления в первый брак и рождения первого ребенка оказались сближенными до предела (Захаров 2007: 81-82): начала происходить легитимация добрачных сексуальных практик, но эффективные средства контрацепции еще оставались недоступными для большинства россиян, поэтому добрачные связи часто приводили к незапланированным беременностям. Легитимации внебрачных рождений и одинокого родительства (в основном, это касалось матерей-одиночек) еще не произошло, поэтому возникавшие беременности зачастую прикрывались браками «вдогонку».

Ф. Биллари и А. Лифбрур выявили (Billari, Liefbroer 2010), что в европейских странах происходит постарение возрастных профилей наступления стартовых событий. Возраст обретения социоэкономических событий, в среднем, меняется меньше, чем возраст обретения демографических событий. За счет этого переход во взрослую жизнь начинается примерно в том же возрасте, что и раньше, а заканчивается позже. В данном исследовании мы изучим, наблюдается ли в России аналогичный процесс, и если наблюдается, то среди каких групп населения.

На основе приведенных исследований мы выдвигаем следующие гипотезы, которые будем проверять в данной работе:

1. Постарение возрастных профилей наступления демографических событий у молодых российских поколений.

2. Переход во взрослую жизнь у молодежи начинается примерно в том же возрасте, что и раньше, а заканчивается позже.

3. Снижение гендерной дифференциации возрастных профилей наступления стартовых событий у молодых поколений.

\section{АНАЛИЗ ВОЗРАСТНЫХ ПРОФИЛЕЙ НАСТУПЛЕНИЯ СТАРТОВЫХ СоБЫтиЙ}

В качестве базы для эмпирического анализа взята российская часть международной программы «Generations and Gender Programme» - репрезентативное для России обследование «Родители и дети, мужчины и женщины в семье и обществе» (РиДМиЖ) 5 .

\footnotetext{
5 Три волны обследования «Родители и дети, мужчины и женщины в семье и обществе» проведены в России Независимым институтом социальной политики в 2004, 2007 и 2011 г. Анкета опросника разработана в 
Нами была использована гармонизированная панельная выборка по состоянию на 2011 г. Объем выборки составил 5451 человека, родившихся в период с 1930 по 1986 годы.

Мы анализировали следующие дебютные события:

- получение школьного образования (изучали только в первой части работы, так как в динамике наступления этого события поколенческих и гендерных различий очень мало);

- получение послешкольного образования (сюда входит и высшее, и профессиональное образование);

- трудоустройство на первую работу (работа по трудовой книжке в течение не менее чем шести месяцев);

- отделение от родителей (отдельное проживание от родителей на протяжении не менее чем трех месяцев);

- вступление в первое партнерство (незарегистрированный союз с совместным проживанием в течение не менее чем трех месяцев);

- вступление в зарегистрированный первый брак;

- рождение первого ребенка.

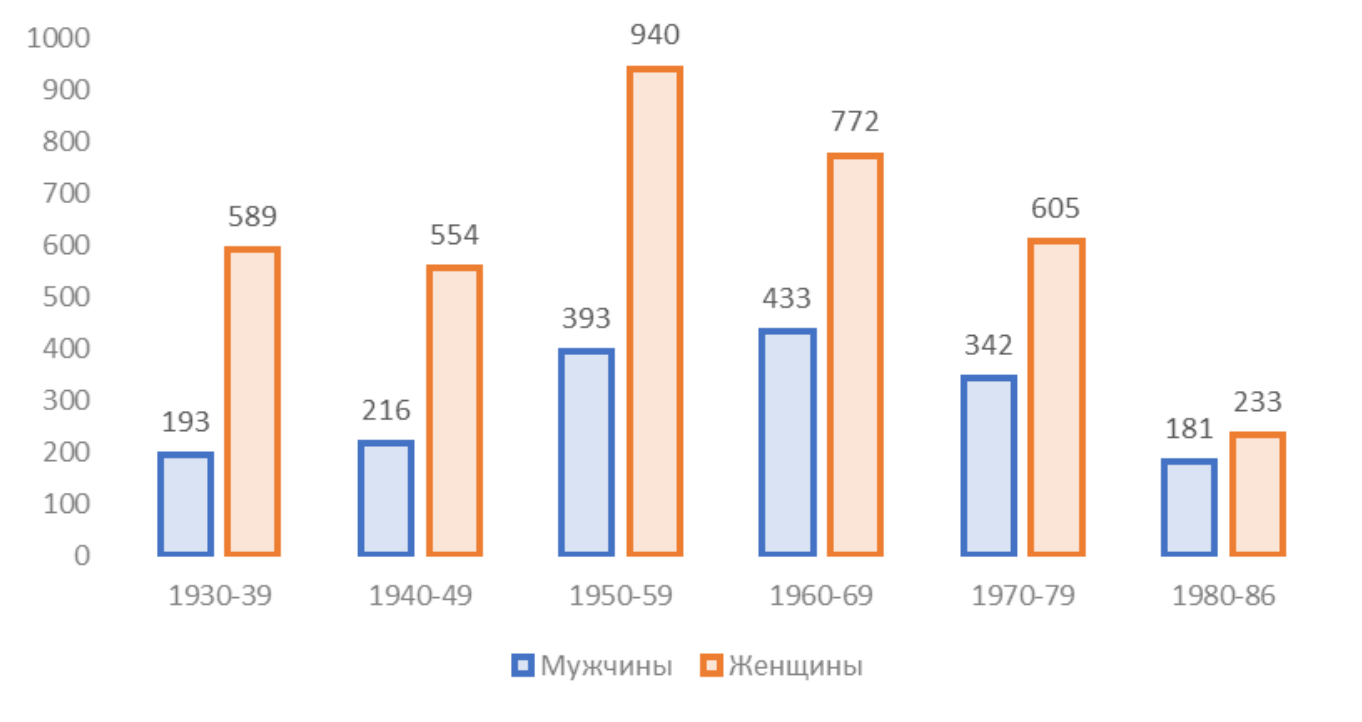

Рисунок 1. Структура выборки в разрезе гендера и поколений

Источник: Составлено автором (панельные данные РиДМиЖ на 2011 г.).

Рисунок 1 репрезентирует структуру выборки в разрезе гендера и поколений. Всего в исследовании анализируются данные 5451 респондента, 67,7\% из которых женщины. Такой гендерный дисбаланс обусловлен обсыпанием выборки; он был нивелирован рассмотрением всех показателей отдельно мужчин и отдельно женщин. Среди мужчин самым многочисленным является поколение 1960-69 г.р., а среди женщин поколение 1950-59 г.р. В целом распределение достаточно близко к половозрастным 
пропорциям населения России в 2011 года ${ }^{6}$, но с погрешностями, которые неизбежны при панельном обследовании.

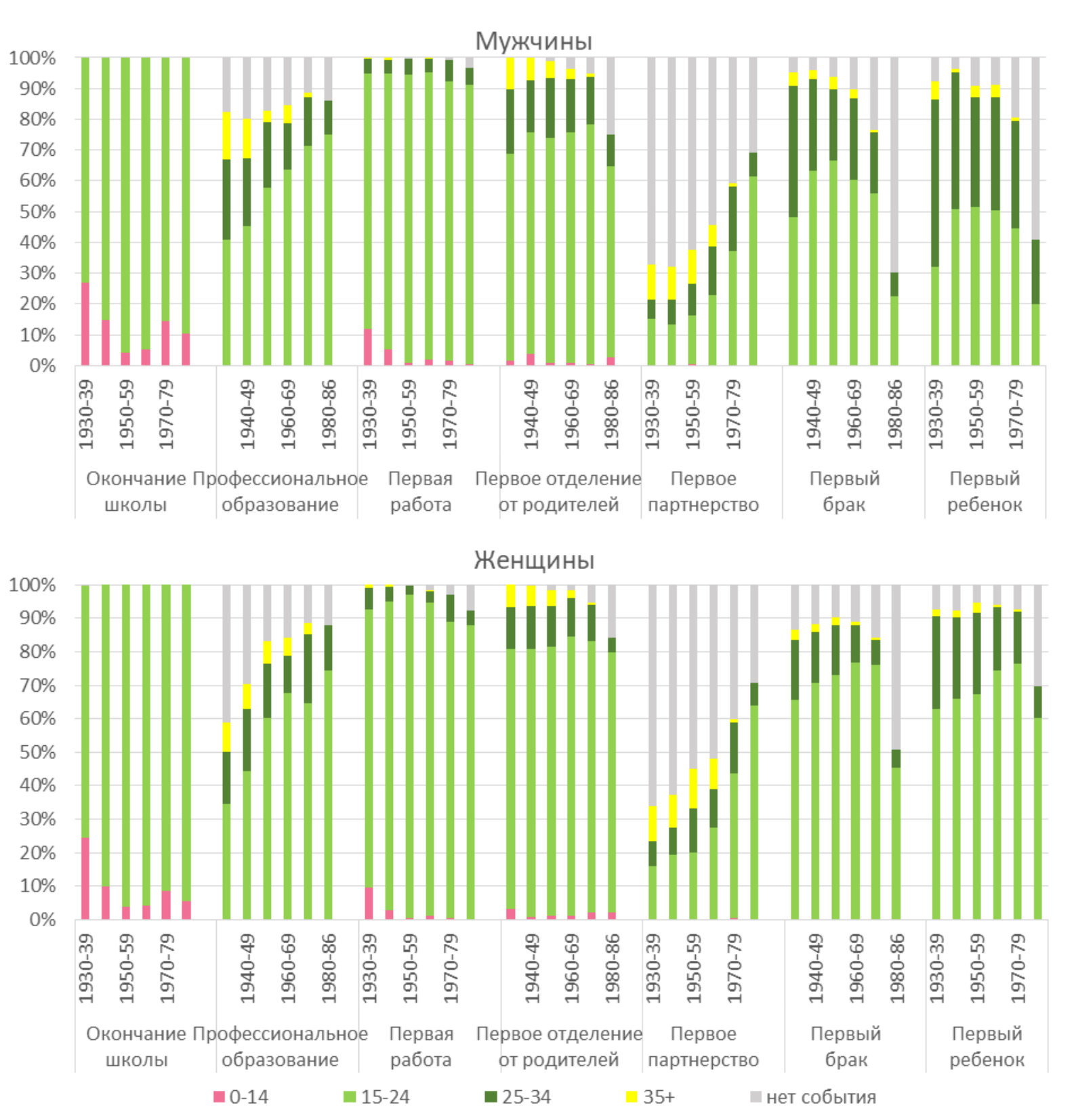

\section{Рисунок 2. Распределение респондентов в зависимости от возраста наступления стартовых событий (в разрезах гендера и поколений)}

Источник: Составлено автором (панельные данные РиДМиЖ на 2011 г.).

Рисунок 2 отображает факты наступления событий в разных интервалах возрастов. Мы видим, что большинство событий наступает у респондентов в период 15-24 лет. Особенно это характерно для социоэкономических событий. Демографические события чаще откладываются до 25-34 лет (особенно мужчинами). Мы намеренно обозначили

\footnotetext{
${ }^{6}$ Актуальную половозрастную пирамиду России можно построить в интерактивном приложении Федеральной службы государственной статистики по ссылке: URL: http://www.gks.ru/wps/wcm/connect/rosstat_main/rosstat/ru/apps/ 
интервалы 15-24 и 25-34 года на гистограммах разными оттенками одного цвета, чтобы наглядно показать, что большинство стартовых событий наступает именно в период с 15 до 34 лет.

Гендерная разница почти отсутствует в наступлении таких событий, как окончание школы, трудоустройство и вступление в первое партнерство. А для остальных событий гендерные различия в той или иной степени присутствуют. Среди мужчин доля тех, кто имеет профессиональное образование, больше, чем среди женщин. Особенно это характерно для советских поколений. Отделение от родителей, вступление в первый брак и рождение первого ребенка у женщин происходит в более ранних возрастах и более интенсивно.

Межпоколенческая разница отсутствует только для окончания школы. Совсем минимальная разница - в трудоустройстве и отделении от родителей: у самых молодых эти события происходят чуть менее интенсивно. Резкий рост интенсивности обретения событий характерен для получения профессионального образования и вступления в первое партнерство. Резкий спад характерен для первых браков и деторождений.

До 1970-х годов в России и в западных странах рождаемость сдвигалась к молодым возрастам (Захаров 2013: 292). В 1980-е годы, когда в западных странах возраст деторождения стал увеличиваться, меры российской демографической политики способствовали сохранению довольно ранних возрастов деторождения. Сегодня в России происходит сдвиг рождаемости в более поздние возрасты, но отставание от западных стран еще существенно. В 2007-2011 гг. рождаемость 30-летних матерей выросла более чем в два раза по сравнению с 1999 г. (Захаров 2013: 293). Сравнение данных переписи населения 2010 г. и данных текущего учета (Ипатова, Тындик 2015: 125) показывают, что, начиная с 1995 г. возраст матери при рождении первого ребенка непрерывно растет. В 2011 г. этот показатель составил 25,5 года. С.В. Захаров оценивает аналогичный показатель в 24,9 года (Захаров 2018: 202).

Начиная с 1950-х годов протогенетический интервал непрерывно уменьшался. Если в середине века он составлял немного меньше 2 лет, то к концу века снизился всего до 6 месяцев (Вишневский 2006: 191; Сифман 1968). Это снижение протогенетического интервала является наглядной демонстрацией роста браков, форсированных незапланированной беременностью. С 1990-х годов начал увеличиваться вклад во внебрачную рождаемость 20-35-летних, т.е. женщин в возрастах максимальной брачности (Архангельский 2006: 171; Вишневский 2006: 106). Наблюдаемые изменения можно проинтерпретировать как то, что, начиная с 1990-х годов случайная беременность перестает являться достаточным поводом для регистрации брака, а значит, меняется и само отношение к добрачному сексуальному поведению.

Для того, чтобы изучить возрастные профили наступления стартовых событий, мы посчитали медианные возрасты для каждого из шести событий. В таблице П1 Приложения приведены медианы как для всех событий (эти значения будут использоваться дальше), так и только для тех событий, которые наступили в диапазоне 15-35 лет. Для того, чтобы сделать межпоколенческие сопоставления наглядными, мы разместили полученные 
значения возрастов на демографической сетке Лексиса (Пресса 1966) (рисунок 3). Использование такого инструмента позволяет визуализировать не только тайминг наступления событий, но также их интенсивность, композицию, последовательность (Митрофанова 2019).

Ось X на сетке Лексиса представляет календарное время, ось Y соответствует возрастам поколений в каждый момент времени, а диагональная ось - когортам по дате рождения (поколениям). Пиктограммы обозначают медианные возрасты наступления стартовых событий. Для социоэкономических событий у мужчин использованы зеленые цвета, для демографических - синие; для социоэкономических событий у женщин оранжевые, для демографических - красные. Для наглядности пиктограммы одного цвета обведены рамкой соответствующего цвета.

Плотность заливки пиктограмм соответствует информации, представленной на рисунке 2, и обозначает следующее: если заливка насыщенная, это значит, что событие произошло более чем у $70 \%$ представителей конкретного поколения и гендера, если заливка полупрозрачная и в рамке - у 50-70\%, если полупрозрачная без рамки - менее чем у 50\% респондентов.
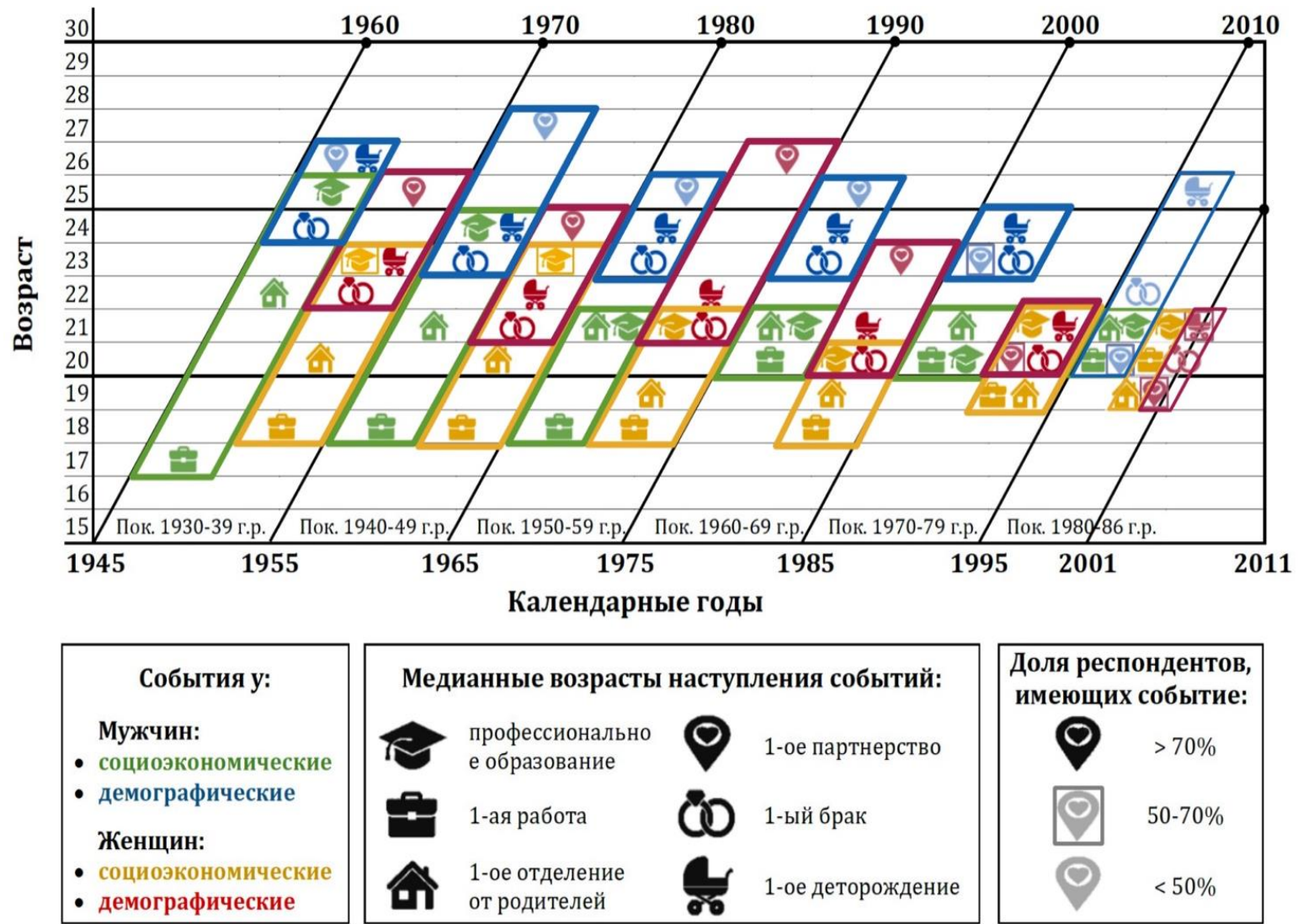

\section{Рисунок 3. Медианные возрасты наступления стартовых событий на демографической сетке Лексиса (вариант Р. Пресса (Пресса 1966))}

Источник: Составлено автором (панельные данные РиДМиЖ на 2011 г.).

Сетка Лексиса наглядно демонстрирует, как меняются возрастные профили наступления стартовых событий. Все события сдвигаются в более поздние возрасты, однако 
неизменным остается то, что они наступают блоками: сначала социоэкономические (получение образования, трудоустройство, отделение от родителей), а затем демографические (вступление в союзы и деторождение). Первым событием при переходе во взрослую жизнь практически для всех поколений является трудоустройство. У тех, кто родился с 1930 по 1959 г., трудоустройство наступало в 18 лет, а у самых старших мужчин - даже в 17 лет. Самые молодые поколения начинают работать с 20 лет, причем это событие не обязательно является дебютным в социоэкономической сфере. У женщин, например, первым событием является отделение от родителей, что может быть связано с образовательной миграцией или переездом в дом партнера/мужа.

Демографические события у всех поколений наступают компактно, что говорит о тесной связи матримониальных и репродуктивных событий. Наиболее примечательны здесь два сюжета. Первый - про кардинальное изменение позиции партнерств: они не только сдвигаются с задворок взросления на дебютное место, опережая все прочие события (даже социоэкономические), но и количественно начинают преобладать над браками. Если в старших поколениях в партнерствах состояло менее $50 \%$ респондентов, то самые молодое поколение уже к своим 25-30 годам демонстрирует долю в 50-70\%.

Второй сюжет - это размыкание связи между вступлением в союз и деторождением. Во всех поколениях (кроме самых старших и самых молодых мужчин) брак и деторождение стоят на соседних ступенях: деторождение наступает сразу после брака с интервалом менее года. Если флуктуация в самом старшем поколении была временной и связанной со взрослением этого поколения в военное время, то небывалое расстояние между браком и деторождением у молодых мужчин с большой долей вероятности не является случайным и временным. Такое поведение предсказано теорией второго демографического перехода и наблюдается во всех странах, идущих по этому пути.

Несмотря на сказанное выше, медианные возрасты самого молодого поколения надо воспринимать как промежуточные, так как на рисунке 2 видно, что демографические события еще точно наступили не в полном объеме, а значит, медианные возрасты для них будут сдвигаться все выше и выше по сетке Лексиса. Та скученность событий, которую мы сейчас наблюдаем в этом поколении (особенно у женщин) - это следствие цензурирования событий (т.е. респонденты еще слишком молоды и просто не успели реализовать свои репродуктивные и матримониальные намерения в события).

Этот недостаток помогает нивелировать анализ наступления событий в динамике. Рисунок 4 демонстрирует, как происходит обретение стартовых событий во времени. Мы сопоставили разные поколения в одних и тех же возрастах, начиная от 15 лет и заканчивая 35 годами. Графики отражают кумулятивное увеличение доли представителей каждого поколения, имеющих искомое событие.

Визуальный анализ графиков показывает, что у поколений, взрослевших в советское время, между кривыми есть заметные расстояния, т. е. выражена поэтапность наступления событий, тогда как у молодых поколений события начинают перемешиваться. Большинство советских поколений начинало переход во взрослую жизнь с трудоустройства и отделения от родителей, а представители молодого поколения не имеют приоритетных событий. 

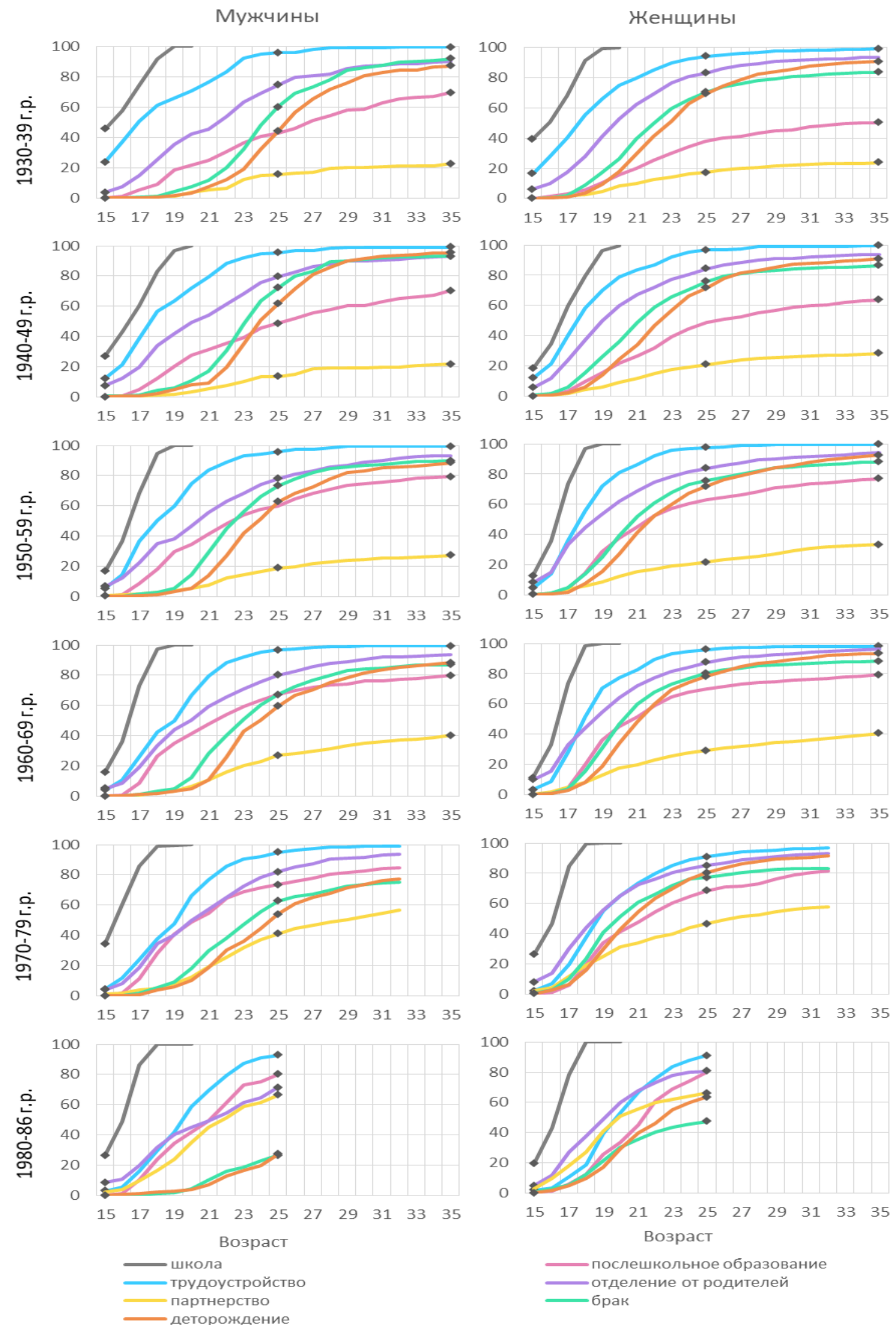

Рисунок 4. Накопленная к возрасту доля мужчин и женщин, имевших опыт наступления событий, Россия, поколения 1930-1986 годов рождения, \%

Источник: Составлено автором (панельные даннье РиДМиЖ на 2011 г.). 
Вариативность жизненных сценариев ярче всего представлена у женщин. Если у молодых мужчин социоэкономические события и партнерство образуют плотный кластер, за границами которого с огромным отставанием во времени идут брак и деторождение, то для молодых женщин, судя по таймингу и интенсивности наступления событий, приоритетно все: и социоэкономические, и демографические статусы.

У всех поколений, кроме самого молодого, первое трудоустройство и отделение от родителей представляют собой «арки», внутри которых появляются остальные события. То есть обретение финансовой и территориальной независимости - первый приоритет или наиболее вынужденная мера для всех российских поколений (кроме самых молодых). Наступление остальных событий различается в зависимости от гендера: до 22-25 лет у мужчин 1930-69 г.р. преобладает получение высшего образования, а после этого возраста резко возрастает доля респондентов, ставших мужьями и отцами. У женщин сразу же после трудоустройства и отделения от родителей происходит создание семьи, а профессиональное образование оставалось одним из наименее популярных событий.

У молодых поколений окончание школы и остальные события все больше отдаляются друг от друга во времени. Это значит, что между окончанием школы (окончанием периода детства) и наступлением социодемографических событий (началом периода взросления) появляется некоторая пауза, которая, скорее всего, говорит о том, что респонденты массово начинают получать профессиональное образование. То есть между окончанием детства и началом взрослости у молодых поколений появляется отдельный период жизни - студенческие годы. Согласно Э. Эриксону, индивиды могут использовать студенческие годы как «психосоциальный мораторий» (Erikson 1995) - период, когда легитимация индивида в обществе уже произошла и он может включаться во взрослые практики (голосовать, работать, вступать в романтические отношения, употреблять алкоголь, водить автомобиль и др.), но так как индивид занят получением образования, то кроме этого от него обычно больше ничего не требуется. Это время, которое индивиды посвящают поиску себя, изучению мира и определению своего места в нем.

Еще одно важное изменение - это превращение партнерства из маргинального события, исключенного из жизни большинства россиян, в одно из приоритетных событий, тесно переплетенного с остальными. Профессиональное образование и партнерство - два события, которые кардинально изменили свое место в иерархии наступления событий всего за полвека.

Для всех событий, кроме окончания школы (так как дифференциации тайминга в наступлении этого события не обнаружено), были построены модели пропорциональных рисков - регрессии Кокса (event history analysis). Для всех событий в качестве точки отсчета (момента попадания в группу риска) было взято 15-летие.

Гендер и поколения были включены в модель в качестве стратифицирующих переменных. В качестве независимых переменных были взяты уровень образования (высшее, профессиональное, общее), тип населенного пункта (областные центры; города и поселки городского типа; сельские населенные пункты), факт смены населенного пункта (не менялся, нисходящая мобильность, восходящая мобильность), число детей (нет детей, 
1-4 ребенка). Интерпретация регрессионных коэффициентов моделей приведена в таблице П2 Приложения, а на рисунке 5 отражены графики функций риска наступления событий.
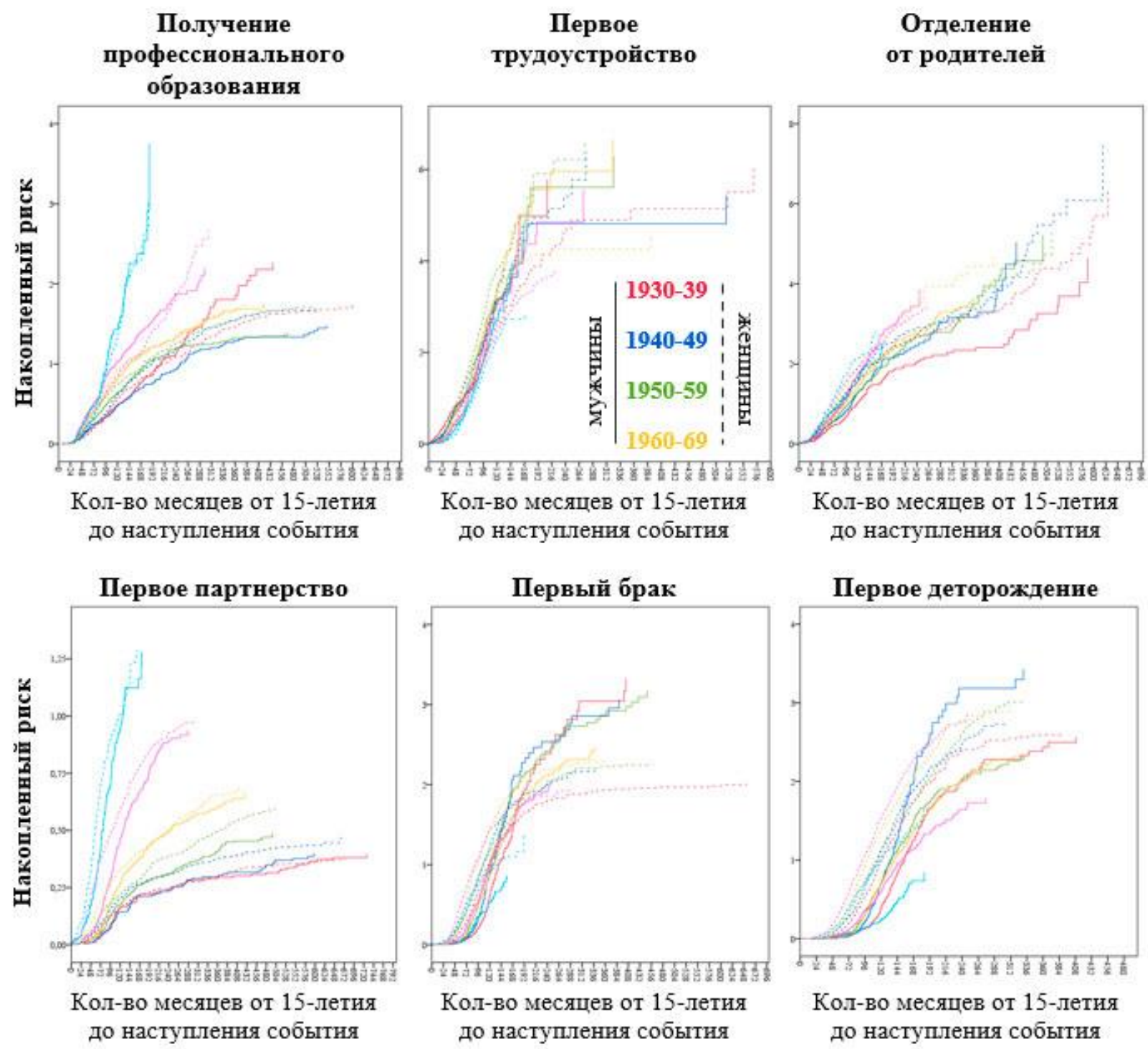

\section{Рисунок 5. Накопленные риски наступления стартовых событий после достижения респондентами 15 лет (в разрезе пола и поколений)}

Источник: Составлено автором (панельные данные РиДМиЖ на 2011 г.).

Приведем краткую интерпретацию результатов по каждой модели.

Гендерная разница в завершении получения профессионального образования почти отсутствует до 25 лет. После этого возраста шансы женщин на получение профессионального образования начинают снижаться, тогда как у мужчин продолжают расти. Мы полагаем, что это связано с большей вовлеченностью женщин в уход за детьми. Имеющаяся межпоколенческая разница, скорее всего, связана с конъюнктурными изменениями и ростом популярности и доступности профессионального образования у молодежи: к возрасту 25 лет уже почти 80\% молодого поколения имеет профессиональное образование, тогда как для советских поколений эта цифра даже к возрасту 35 лет не 
превышала 70\%. Причем молодежь учится не только больше, но и дольше, из-за чего также происходит откладывание выхода на рынок труда. В целом, чем более высокий уровень образования у респондента, тем он (что ожидаемо и логично) позднее завершает обучение. Респонденты со средним уровнем образования покидают учебные заведения, начиная с 17 лет, а респонденты с высшим образованием - после 23 лет. Жители села менее активно получают профессиональное образование, а те, кто его получают, часто совершают образовательную мобильность (и тогда это взаимосвязано с отделением от родителей).

Молодые поколения выходят на рынок труда гораздо позднее и медленнее старших поколений, начиная трудоустраиваться не раньше, чем в 16-17 лет, тогда как советские поколения начинали работать еще до достижения 15 лет. У мужчин несколько меньше шансов начать работать в 19-23 года, а после 25 лет они начинают опережать женщин. Те, у кого низкий уровень образования, выходят на рынок труда раньше всех - в 16-17 лет; те, у кого средний уровень образования - в 17-19 лет, а респонденты с высоким уровнем образования начинают трудоустраиваться после 20 лет. В сельской местности интенсивность выхода на рынок труда ниже, чем в областном центре.

Для отделения от родителей характерны гендерные различия: женщины покидают родительский дом раньше и интенсивнее мужчин. Это может быть связано с переездом в дом мужа после вступления в брак. С 17 до 30 лет женщины активно покидают родительские дома. У жительниц областных центров на всем периоде наблюдения и особенно после 30 лет вероятность переезда меньше, чем у жительниц сел, городов и поселков городского типа. Если покидание родительского дома у женщин мы предварительно связываем с демографическим событием (вступлением в брак), то у мужчин отделение от родителей больше обусловлено социоэкономическими факторами (служба в армии, образовательная и трудовая мобильность). Во всяком случае, у мужчин сильные различия наблюдаются именно в разрезе уровней образования (которые имеют непосредственную взаимосвязь и с опытом срочной службы, и с трудоустройством). Чем более высокий уровень образования получил или получит мужчина, тем в более раннем возрасте произошло его отделение от родителей. Мужчины с высшим образованием активно отделяются от родителей до 20 лет, а после 23 лет начинают интенсивно переезжать от родителей низкообразованные мужчины. Для низко- и высокообразованных мужчин после 27 лет интенсивность отделения от родителей снижается, а для мужчин со средним образованием - растет. Мы предполагаем, что высокообразованные мужчины переезжают от родителей по причине образовательной миграции, низко- и среднеобразованные - из-за трудовой мобильности или по другим причинам.

Наибольшие шансы вступления в первое партнерство показывают молодые жители областных центров, городов и поселков городского типа с низким или средним уровнями образования. Среди советских поколений наибольшие шансы - у жителей областных центров. Мужчины активно вступают в первые партнерства в возрастах 18-25 лет, а после 25-30 лет у всех кроме жителей областных центров интенсивность вступления в партнерства снижается. Советские женщины демонстрируют низкие шансы вступления в партнерства, но молодые жительницы областных центров вступают в партнерства раньше и интенсивнее мужчин, живущих в областных центрах. 
Жители городов и поселков городского типа имеют более высокие шансы вступления в первый брак, чем жители областных центров. Респонденты со средним уровнем образования имеют более высокие шансы вступления в первый брак, чем респонденты с высоким уровнем образования. Среди поколений самые низкие шансы вступить в партнерство - у самого молодого поколения, а самые высокие - у поколения 1970-79 г.p. У мужчин высокая интенсивность вступления в брак наблюдается примерно с 21 года до 30-35 лет. У советских женщин интенсивность вступления в брак высока на протяжении всего наблюдаемого возрастного интервала (с 15 до 35 лет), а у более молодых поколений женщин после 25 лет происходит стагнация интенсивности риска вступления в первый брак. Скорее всего, это следствие селективности: если женщина настроена на брак, то вступает рано, а те, кто не вступают в брак до 25, видимо, пробуют другие формы совместного проживания, и если в итоге и вступят в брак, то, вероятно, уже после 30-35 лет.

Интенсивнее всего первого ребенка рожают молодые женщины, живущие в городах, не являющихся региональными центрами, в поселках городского типа и в сельской местности, а также имеющие низкий или средний уровень образования. Вероятно, это связано с особенностями легитимации добрачных половых отношений и с низкой доступностью контрацептивов в негородской среде или низкой контрацептивной грамотностью женщин с невысоким уровнем образования. Среди женщин наименьшие риски появления первого ребенка наблюдаются у высокообразованных жительниц областных центров, городов и поселков городского типа вне зависимости от принадлежности к поколению. Интенсивность деторождений у молодых женщин разных поколений в одних и тех же возрастах очень похожа и высока (особенно на фоне мужчин). Можно отметить небольшое замедление темпов деторождения только после 35 лет, что может быть связано с сохранением среди российских женщин советской идеальной модели поведения - стремлением стать матерью до 30.

Таким образом, получение образования и первое партнерство - это два события, относительно которых поведение поколений различается очень сильно, тогда как гендерная разница (особенно у молодых) почти отсутствует. Трудоустройство и отделение от родителей наступают у разных поколений и разных гендеров в довольно близком диапазоне возрастов с очень похожей динамикой. Вступление в брак и деторождение - это события, в наступлении которых прослеживается гендерная дифференциация (женщины обретают эти события раньше и интенсивнее, чем мужчины), а также начинают наблюдаться поколенческие сдвиги (молодые мужчины сильно откладывают эти события).

Мы можем сделать следующие выводы по выдвинутым гипотезам:

1. У молодых российских поколений наблюдается постарение возрастных профилей наступления демографических событий: браки и деторождения откладываются. Однако партнерство сдвигается в ранние возрасты, что делает его дебютным демографическим событием.

2. Переход во взрослую жизнь у молодежи начинается примерно в том же возрасте, что и раньше, а заканчивается позже. Это происходит за счет того, что социоэкономические события наступают примерно в тех же возрастах, что и раньше, а демографические события откладываются. 
3. Поведение молодых мужчин и женщин и в социоэкономической, и в демографической сфере сближается, хотя женщины всё еще активнее и в более ранних возрастах создают семьи.

\section{ЗАКЛЮЧЕНИЕ}

Проведенный анализ показал, что современная молодежь более вариативно выбирает время для взросления - особенно, когда это касается таких «неотменяемых» событий, как создание семьи и рождение ребенка. В откладывании браков и деторождений усматривается осваивание молодежью инструментов планирования и довольно ответственный подход к взятию на себя ответственности, когда лучше отложить на попозже, чем столкнуться с долгосрочными последствиями.

В социоэкономической сфере молодежь наследует предыдущим поколениям, трудоустраиваясь и отделяясь от родителей примерно в тех же возрастах и с той же интенсивностью, что и раньше (до 20-25 лет). Среди демографических событий по-настоящему дебютный смысл обретает партнерство, обгоняя браки и деторождения, а может, и замещая их (это нам еще предстоит изучать).

Результаты исследования демонстрируют трансформацию возрастных профилей наступления стартовых событий у россиян и подтверждают наличие в России признаков второго демографического перехода (Вишневский 2006; Frejka, Zakharov 2012; Puur et al. 2012). Выявленные закономерности наступления стартовых событий жизненного пути совпадают с тенденциям, характерными для европейских стран (Billari, Liefbroer 2007): возраст обретения социоэкономических событий в России так же, как и в европейских странах, меняется меньше, чем возраст наступления демографических событий. За счет этого переход во взрослую жизнь начинается примерно в том же возрасте, что и раньше, а заканчивается позже. Агентами модернизации в России являются самые молодые поколения (те, которые социализировались после распада СССР) и мужское население.

\section{БЛАГОДАРНОСТИ}

Автор выражает благодарность за многолетнюю поддержку и научное консультирование всем коллегам, оказавшим помощь в подготовке данного исследования. Прежде всего, научному руководителю С.В. Захарову, а также участникам двух научно-учебных групп НИУ ВШЭ «Изучение рождаемости, формирования, развития и распада семей на данных выборочных обследований» и «Модели и методы анализа демографических последовательностей», в особенности А.О. Макаренцевой, Д.И. Игнатову, Т.Н. Еspy, О.В. Синявской, А.В. Артамоновой, А.А. Муратовой, Д.К. Гиздатуллину, С.С. Бирюковой и А.А. Долговой.

Также автор благодарит за рецензирование разных частей данной работы на разных стадиях ее подготовки коллег из российских и зарубежных университетов и научных центров: А. Puur, В.С. Магуна, Е.Ю. Рождественскую, А.Г. Вишневского, М.С. Фабрикант, 
A.A. Авдеева, A. Blum, F. Billari, M. Mills, L. Sakkeus, L. Rahnu, P. Blanchard, R. Leu, L. Toulemon, E. Lelièvre, M. Bouchet-Valat, L. Moulin.

\section{ЛИТЕРАТУРА}

Арутюнян М.Ю. (1997). Гендерные отношения в семье. В Материаль Первой Российской летней школы по женским и гендерным исследованиям «Валдай-96» (сс. 136-141). Москва: МЦГИ.

Архангельский В.Н. (2006). Факторы рождаемости. Москва: ТЕИС.

Беляева Л.А. (2004). Социальный портрет возрастных когорт в постсоветской России. Социологические исследования, 10, 31-42.

Вишневский А.Г., Кон И.С. (Ред.) (1979) Брачность, рождаемость, семья за три века. Москва: Статистика.

Вишневский А.Г., Тольц М.С. (1988). Эволюция брачности и рождаемости в советский период. В Население СССР за 70 лет (сс. 75-114). Москва: Наука.

Гимпельсон В.Е., Зудина А.А. (2017). Демографические проблемы рынка труда. Демоскоп Weekly, 729-730. URL: http://www.demoscope.ru/weekly/2017/0729/tema01.php

Голод С.И. (2005). Что было пороками, стало нравами. Лекции по соичиологии сексуальности. Москва: Ладомир.

Дарский Л.Е., Ильина И.П. (1990). Нормализация брачности в СССР. В Демографические проиессы в СССР (сс. 6-27). Москва: Наука.

Вишневский А.Г. (Ред.) (2006) Демографическая модернизация России, 1900-2000. Москва: Новое издательство.

Денисенко М.Б., Далла Зуанна Ж.-П. (2001). Сексуальное поведение российской молодежи. Сочиологические исследования, 2, 83-87.

Долгова А.А., Митрофанова Е.С. (2015). Отделение от родителей в России:

Межпоколенческий аспект. Экономическая сочиология. URL: https://publications.hse.ru/articles/168019618

Захаров С.В. (2006). Возрастная модель брака. Отечественные записки, 4(31), 271-300.

Захаров С.В. (2007). Трансформация брачно-партнерских отношений в России: «золотой век» традиционного брака близится к закату? В Родители и дети, мужчины и женщины в семье и обществе. Выпуск 1. Москва: НИСП.

Захаров С.В. (2009). Ценностно-нормативные «расписания» человеческой жизни: Представления жителей разных стран о том, когда девушка становится взрослой. В Россия в Европе. По материалам международного проекта «Европейское соииальное исследование» (сс. 347-379). Москва: Academia.

Захаров С.В. (2013). Рождаемость и воспроизводство населения. В Население России 2010-2011: Восемнадиатый-девятнадиатый ежегодный демографический доклад (сс. 276-385). Москва: Издательский дом Высшей школы экономики.

Захаров С.В. (2018). Рождаемость и планирование семьи в России. В Население России 2016: Двадиать четвертый ежегодный демографический доклад (сс. 186-259).

Москва: Издательский дом Высшей школы экономики. 
Здравомыслова Е.А., Темкина А.А. (2008). История и современность: Гендерный порядок в России. В Гендер для «чайников» (сс. 55-85). Москва: Звенья. URL: http://medbooks.info/psihologiya-gendernaya/gender-dlya-chaynikov.html

Здравомыслова Е., Темкина А. (2004). От лицемерия к рационализации: Дискурсивная трансформации в сфере сексуальных отношений. Гендерные исследования, 11, 176186.

Здравомыслова О.М., Шурыгина И.И. (2001). Выжить или преуспеть: Представления старшеклассников о своих жизненных шансах. В Кто и куда стремится вести Россию? Акторы макро-, мезо- и микроуровней современного трансформачионного прочесса (cc. 366-374). http://ecsocman.hse.ru/data/250/679/1219/048.ZDRAVOMYSLOVA.pdf

Ипатова А.А., Тындик А.О. (2015). Репродуктивный возраст: 30-летний рубеж в предпочтениях и биографиях. Мир России, 4, 123-148.

Кон И.С. (1997). Сексуальная культура в России: Клубничка на березке. Москва: ОГИ (Объединенное Гуманитарное Издательство).

Кон И.С. (2010). Три в одном: Сексуальная, гендерная и семейная революции. Демоскоп Weekly, 447-448.

Константиновский Д.Л. (2008). Неравенство и образование. Опыт социологических исследований жизненного старта российской молодежи (1960-е годы-начало 2000-х). Москва: Центр социального прогнозирования.

Митрофанова Е.С. (2019). Модели взросления разных поколений россиян. Демографическое обозрение, 6(4), 53-82. https://doi.org/10.17323/demreview.v6i4.10427

Митрофанова Е.С., Артамонова А.В. (2015). Последовательность жизненных событий у российских мужчин, служивших и не служивших в армии. Демографическое обозрение, 4, 5-36. https://doi.org/10.17323/demreview.v2i4.1769

Пресса Р. (1966). Народонаселение и его изучение: Демографический анализ. Статистика.

Ремшмидт Х. (1994). Подростковый и юношеский возраст: Проблемы становления личности. Москва: Мир. http://www.childpsy.ru/lib/books/id/8335.php

Семья и рождаемость: Основные результаты выборочного обследования. 2009 год. (2010). Москва: ИИЦ «Статистика России».

Сифман Р.И. (1968). Интервалы между рождениями и между вступлением в брак и первым рождением. В Изучение воспроизводства населения (сс. 107-133). Москва: Наука.

Тольц М.С. (1974). Характеристика некоторых компонентов рождаемости в большом городе. В Демографический анализ рождаемости (сс. 45-55). Москва: Статистика.

Тольц М.С. (1977). Брачность населения России в конце XIX - начале XX в. В Брачность, рождаемость, смертность в России и в СССР (сс. 138-153). Москва: Статистика.

Троицкая И., Авдеев А., Капанадзе Е., Третьякова В. (2010). Сравнительный анализ контрацептивного поведения: Франция, Грузия, Литва и Россия. В Эволюиия семьи 8 Европе: Восток-Запад (сс. 266-304). Москва: НИСП.

Benjamin A., Crymble S.B. (2017). A Re-Imagination of the Transition to Adulthood. A. Laros, T. Fuhr, E.W. Taylor (Ред.), Transformative Learning Meets Bildung (pp. 247-258).

SensePublishers. URL: https://doi.org/10.1007/978-94-6300-797-9_20 
Billari F.C., Hagestad G.O., Liefbroer A.C., Spéder Z. (2005). The Timing of Life: The Organization of the Life Course in Europe. The timing of life: The organisation of the life course in Europe. European Social Survey. URL:

http://www.europeansocialsurvey.org/docs/round3/questionnaire/ESS3_billari_proposal.pdf

Billari F.C., Liefbroer A.C. (2010). Towards a new pattern of transition to adulthood? Advances in Life Course Research, 15(2), 59-75.

Billari F.C., Hagestad G.O., Liefbroer A.C., Zsolt S. (2005). Question Module Design Team (ESS Round 3) Application Form: The Timing of Life: The Organization of the Life Course in Europe. URL:

http://www.europeansocialsurvey.org/docs/round3/questionnaire/ESS3_billari_proposal.pdf

Billari F.rancesco C., Liefbroer A.C. (2007). Should I Stay or Should I Go? The Impact of Age Norms on Leaving Home. Demography, 1, 181. URL: https://doi.org/10.2307/4137227

Blum A., Sebille P., Zakharov S.V. (2009). A divergent transition to adulthood in France and Russia: A cohort approach. Revue d'Etudes Comparatives Est-Ouest, 40(3-4), 123-152.

Buchmann M. (1989). The script of life in modern society: Entry into adulthood in a changing world. Chicago: University of Chicago Press.

Corijn M., Klijzing E. (2001). Transitions to adulthood in Europe. Springer. URL: http://dx.doi.org/10.1007/978-94-015-9717-3

Erikson E.H (1995). Identity: Youth and Crisis. New York: W. W. Norton \& Company.

Espy IV T.H., Mitrofanova E.S. (2017). Sequence Analysis of the Migration Biographies of Russians (SSRN Working Paper ID 3071733). Social Science Research Network.

Frejka T., Zakharov S. (2012). Comprehensive analyses of fertility trends in the Russian Federation during the past half century. Max Planck Institute for Demographic Research. Series «MPIDR Technical Report». No. WP2012-027.

Gabriel F. (2013). Deconstructing Youth. Palgrave Macmillan UK. URL: https://doi.org/10.1057/9781137317520

Gauthier A.H. (2007). Becoming a Young Adult: An International Perspective on the Transitions to Adulthood. European Journal of Population, 23(3-4), 217-223. URL: https://doi.org/10.1007/s10680-007-9130-x

Giddens A. (1994). Living in a post-traditional society. Reflexive Modernization; Politics, Tradition and Aesthetics in the Modern Social Order (pp. 56-109). Cambridge, UK: Polity Press; Blackwell.

Heinz W.R., Marshall V.W. (2003). Social dynamics of the life course: Transitions, institutions, and interrelations. New York: Aldine de Gruyter.

Horowitz A.D., Bromnick R.D. (2007). "Contestable Adulthood": Variability and Disparity in Markers for Negotiating the Transition to Adulthood. Youth, Society, 39(2), 209-231. URL: https://doi.org/10.1177/0044118X06296692

Huinink J. (2013). De-Standardisation or Changing Life Course Patterns? Transition to Adulthood from a Demographic Perspective. The Demography of Europe (pp. 99-118). Springer Netherlands. URL: https://doi.org/10.1007/978-90-481-8978-6_5

Liefbroer A.C. (1999). From Youth to Adulthood: Understanding Changing Patterns of Family Formation from a Life Course Perspective. Population Issues (pp. 53-85). The Netherlands: Springer. 
Lowe S.R., Dillon C.O., Rhodes J.E., Zwiebach L. (2013). Defining Adult Experiences: Perspectives of a Diverse Sample of Young Adults. Journal of Adolescent Research, 28(1), 31-68. URL: https://doi.org/10.1177/0743558411435854

Mitrofanova E.S. (2016). Russian Generations: Sequencing the Transition to Adulthood. Proceedings of the International Conference on Sequence Analysis and Related Methods (LaCOSA II) (pp. 263-275). Lausanne: LaCOSA II. URL: https://publications.hse.ru/chapters/185791867

Popov A.A., Visser A. Ph., Ketting E. (1993). Contraceptive Knowledge, Attitudes, and Practice in Russia during the 1980s. Studies in Family Planning, 24(4), 227-235. URL: https://doi.org/10.2307/2939190

Puur A., Rahnu L., Maslauskaite A., Stankuniene V. (2012). Past and present patterns of family formation in Eastern Europe: Does Hajnal's delineation still matter? Filosofija Sociologija, 23(4), 256-265.

Puur A., Rahnu L., Maslauskaite A., Stankuniene V., Zakharov S. (2012). Transformation of Partnership Formation in Eastern Europe: The Legacy of the Past Demographic Divide. Journal of Comparative Family Studies, 43(3), 389-417.

Raveaud M. (2010). Becoming an Adult in Europe: A Socially Determined Experience. European Educational Research Journal, 9(3), 431-442. URL: https://doi.org/10.2304/eerj.2010.9.3.431

Rindfuss R.R. (1991). The Young Adult Years: Diversity, Structural Change, and Fertility. Demography, 28(4), 493.

Shoven J.B., Goda G.S. (2011). Adjusting Government Policies for Age Inflation. Demography and the Economy (pp. 143-168). Chicago, London: University of Chicago Press. URL: https://doi.org/10.7208/chicago/9780226754758.003.0005

Vikat A., Spéder Z., Beets G., Billari F.C., Bühler C., Désesquelles A., Fokkema T., Hoem J.M., MacDonald A., Neyer G. (2007). Generations and Gender Survey (GGS): Towards a better understanding of relationships and processes in the life course. Demographic research, 17, $389-440$.

Vleioras G., Mantziou A. (2018). Social Role Transitions and Perceived Adulthood Status:

Which Ones Matter for Whom? Emerging Adulthood, 6(3), 200-205. URL:

https://doi.org/10.1177/2167696817722470 


\section{ПРИЛОЖЕНИЯ}

Таблица П1. Медианные возрасты наступления стартовых событий (все события и события в диапазоне 15-35 лет)

\begin{tabular}{|c|c|c|c|c|c|c|c|c|c|c|c|c|c|c|}
\hline \multirow[b]{2}{*}{ Поколения } & \multicolumn{7}{|c|}{ Все события } & \multicolumn{7}{|c|}{ События в диапазоне возрастов 15-35 лет } \\
\hline & 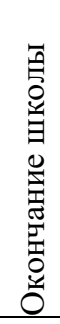 & 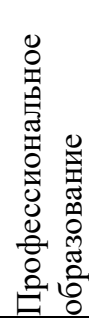 & 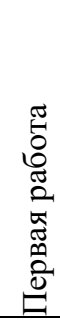 & 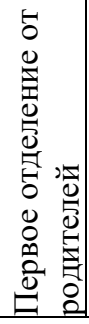 & 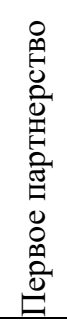 & 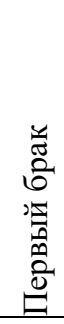 & 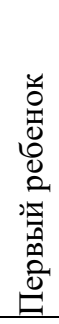 & 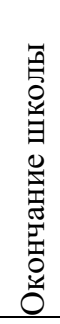 & 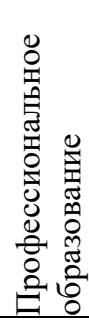 & 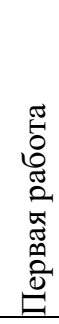 & 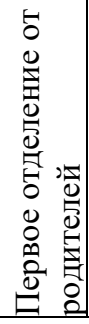 & 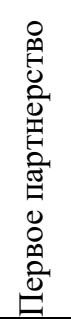 & 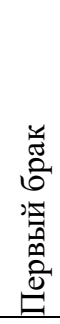 & 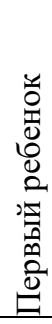 \\
\hline \multicolumn{15}{|c|}{ Мужчины } \\
\hline $1930-1939$ & 16 & 25 & 17 & 22 & 26 & 24 & 26 & 17 & 23 & 18 & 22 & 23 & 24 & 25 \\
\hline $1940-1949$ & 17 & 24 & 18 & 21 & 27 & 23 & 24 & 17 & 22 & 18 & 20 & 24 & 23 & 24 \\
\hline $1950-1959$ & 17 & 21 & 18 & 21 & 25 & 23 & 24 & 17 & 21 & 19 & 21 & 23 & 22 & 24 \\
\hline $1960-1969$ & 17 & 21 & 20 & 20 & 25 & 23 & 24 & 17 & 20 & 20 & 20 & 24 & 23 & 24 \\
\hline $1970-1979$ & 16 & 20 & 20 & 20 & 23 & 23 & 24 & 16 & 20 & 20 & 20 & 23 & 23 & 24 \\
\hline $1980-1986$ & 17 & 21 & 20 & 19 & 20 & 22 & 25 & 17 & 21 & 20 & 19 & 20 & 22 & 25 \\
\hline Всего & 17 & 21 & 19 & 20 & 23 & 23 & 24 & 17 & 21 & 19 & 20 & 23 & 23 & 24 \\
\hline \multicolumn{15}{|c|}{ Женщины } \\
\hline $1930-1939$ & 16 & 23 & 18 & 20 & 25 & 22 & 23 & 17 & 22 & 18 & 20 & 22 & 22 & 23 \\
\hline $1940-1949$ & 17 & 23 & 18 & 20 & 24 & 21 & 22 & 17 & 22 & 18 & 19 & 22 & 21 & 22 \\
\hline $1950-1959$ & 17 & 21 & 18 & 19 & 26 & 21 & 22 & 17 & 21 & 18 & 19 & 22 & 21 & 22 \\
\hline 1960-1969 & 17 & 20 & 18 & 19 & 23 & 20 & 21 & 17 & 20 & 18 & 19 & 22 & 20 & 21 \\
\hline $1970-1979$ & 17 & 21 & 19 & 19 & 20 & 20 & 21 & 17 & 21 & 19 & 19 & 20 & 20 & 21 \\
\hline $1980-1986$ & 17 & 21 & 20 & 19 & 19 & 20 & 21 & 17 & 21 & 20 & 19 & 19 & 20 & 21 \\
\hline Всего & 17 & 21 & 18 & 19 & 23 & 21 & 22 & 17 & 21 & 19 & 19 & 21 & 21 & 22 \\
\hline \multicolumn{15}{|c|}{ Bce } \\
\hline $1930-1939$ & 16 & 24 & 18 & 20 & 25 & 23 & 24 & 17 & 23 & 18 & 20 & 23 & 23 & 24 \\
\hline $1940-1949$ & 17 & 23 & 18 & 20 & 25 & 22 & 23 & 17 & 22 & 18 & 19 & 23 & 22 & 23 \\
\hline $1950-1959$ & 17 & 21 & 18 & 20 & 26 & 22 & 23 & 17 & 21 & 18 & 19 & 23 & 21 & 23 \\
\hline $1960-1969$ & 17 & 20 & 19 & 19 & 23 & 21 & 22 & 17 & 20 & 19 & 19 & 22 & 21 & 22 \\
\hline $1970-1979$ & 16 & 21 & 19 & 19 & 22 & 21 & 22 & 17 & 20 & 19 & 19 & 22 & 21 & 22 \\
\hline $1980-1986$ & 17 & 21 & 20 & 19 & 20 & 21 & 22 & 17 & 21 & 20 & 19 & 20 & 21 & 22 \\
\hline Всего & 17 & 21 & 19 & 20 & 23 & 21 & 23 & 17 & 21 & 19 & 19 & 22 & 21 & 23 \\
\hline
\end{tabular}

Источник: Составлено автором (панельные данные РиДМиЖ на 2011 г.). 


\section{Таблица П2. Регрессии Кокса: интерпретация регрессионных коэффициентов}

\begin{tabular}{l|c|c|c|c|c|c}
\hline \multicolumn{1}{|l}{ Изменение категории } & $\begin{array}{c}\text { Профессиональное } \\
\text { образование }\end{array}$ & $\begin{array}{c}\text { Первая } \\
\text { работа }\end{array}$ & $\begin{array}{c}\text { Отделение } \\
\text { от родителей }\end{array}$ & $\begin{array}{c}\text { Первое } \\
\text { партнерство }\end{array}$ & $\begin{array}{c}\text { Первый } \\
\text { брак }\end{array}$ & $\begin{array}{c}\text { Первый } \\
\text { ребенок }\end{array}$ \\
\hline Чем ниже уровень & выше** & ср=выше & выше** & ср=выше** & выше** \\
образования, тем шансы & & низ=ниже** & & низ=выше & выше \\
наступления события... & & & &
\end{tabular}

\begin{tabular}{|c|c|c|c|c|c|}
\hline $\begin{array}{l}\text { Чем пункт проживания } \\
\text { менее городской и } \\
\text { населенный, тем шансы } \\
\text { наступления события... }\end{array}$ & $\begin{array}{l}\text { ПГТ=ниже } \\
\text { СНП=ниже }\end{array}$ & ниже** & выше** & ниже** & $\begin{array}{l}\text { ПГТ=выше } \\
\text { СНП выше } \\
\text { выше }\end{array}$ \\
\hline
\end{tabular}

\begin{tabular}{|c|c|c|c|c|c|c|}
\hline $\begin{array}{l}\text { Если была смена типа } \\
\text { населенного пункта, то } \\
\text { шансы наступления } \\
\text { события... }\end{array}$ & $\begin{array}{l}\text { нисх }=\text { выше } \\
\text { восх }=\text { ниже }\end{array}$ & & $\begin{array}{l}\text { нисх }=\text { выше } * \\
\text { восх }=\text { выше }\end{array}$ & $\begin{array}{l}\text { нисх }=\text { выше } \\
\text { восх }=\text { выше }\end{array}$ & & \\
\hline $\begin{array}{l}\text { В сравнении с } \\
\text { бездетными, у тех, кто } \\
\text { имеет хотя бы одного } \\
\text { ребенка, шансы } \\
\text { наступления события... }\end{array}$ & $\begin{array}{l}1=\text { =выше } \\
2=\text { выше } \\
3=\text { ниже } \\
4+=\text { ниже } \\
\text { ** }\end{array}$ & & выше ** & $\begin{array}{l}1=\text { выше } \\
2=\text { н/в } \\
3=\text { н/в } \\
4+=\text { выше }\end{array}$ & выше ** & \\
\hline $\begin{array}{l}\text { В сравнении с самыми } \\
\text { молодыми, у остальных, } \\
\text { начиная с самых } \\
\text { пожилых, шансы } \\
\text { наступления события... }\end{array}$ & ниже ** & $\begin{array}{l}\text { 1930- } \\
60= \\
\text { выше** } \\
1970= \\
\text { выше* }\end{array}$ & $\begin{array}{l}1930-50= \\
\text { ниже** } \\
1960-70= \\
\text { ниже }\end{array}$ & ниже** & $\begin{array}{l}1930= \\
\text { выше } \\
1940-70= \\
\text { выше ** }\end{array}$ & $\begin{array}{l}1930= \\
\text { выше* } \\
1940- \\
70= \\
\text { выше** }\end{array}$ \\
\hline $\begin{array}{l}\text { У женщин в сравнении } \\
\text { с мужчинами шансы } \\
\text { наступления события... }\end{array}$ & ниже** & выше* & выше ** & выше** & выше** & выше ** \\
\hline
\end{tabular}

Источник: Составлено автором (панельные данные РиДМиЖ на 2011 г.).

Сокращения:

ср - средний уровень образования

низ - низкий уровень образования

н/в - для незначимых коэффициентов: в зависимости от страты либо выше, либо ниже

Цвет ячеек:

оранжевыц - шансы наступления события понижаются

зеленый - шансы наступления события повышаются

голубой - для одних категорий шансы повыщаются, а для других - понижаются

Значимость коэффициентов:

** коэффициенты значимы на уровне 0,001

* коэффициенты значимы на уровне как минимум 0,1 


\title{
(NO)TIME TO GROW UP: CHANGING AGES OF DEBUT BIOGRAPHICAL EVENTS IN RUSSIA
}

\author{
EKATERINA MITROFANOVA
}

\begin{abstract}
There is an opinion that today's youth is not only in a hurry to became adults, but also refusing to obtain starting life course events that may limit freedom and that require commitment. To test this idea, we studied the ages of the onset of six major biographical events: completion of professional education, first employment, first separation from parents, first partnership (unregistered union), first marriage and birth of the first child.
\end{abstract}

We compared the behaviour of six generations of Russians born between 1930 and 1986. Our sample consisted of 5,451 people from the panel of the Russian part of the Generations and Gender Survey (2004, 2007 and 2011). We not only studied the median ages of the onset of events and presented them on the Lexis grid, but also estimated the chances of obtaining starting events using Cox regressions (event history analysis).

We found that there is no serious postponement of socioeconomic events: employment and separation from parents minimally changed their positions in the schedule of life of young generations. Completion of education has moved to a later age, but this is due to a significant increase in the number of graduates of vocational education of different levels. The age of entry into first partnership in young generations has fallen to a historic low, becoming the earliest of the demographic events. Two other demographic events - first marriage and first childbearing indeed had been postponed by young people, especially men. Thus, our study revealed that young generations are not sabotaging transition to adulthood but they are becoming adults but according to their own life schedules and in their own time.

Key words: Russia, transition to adulthood, generations, age, starting life-course events, demographic events, socioeconomic events, demographic transition, marriage, childbearing, partnership, employment, education, leaving parents, event history analysis, Lexis grid.

EKATERINA Mitrofanova (emitrofanova@hse.ru), NATIONAL RESEARCH UNIVERSITY Higher SchOOL OF Economics, ACADEMY of NATIONAL ECONOMY AND PUblic AdMinistration, Russia.

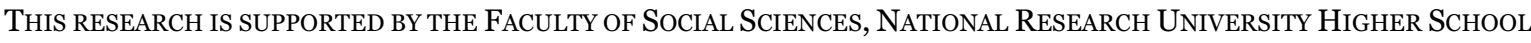
OF ECONOMICS

DATE RECEIVED : NOVEMBER 2020.

\section{REFERENCES}

Arkhangel'skiy V.N. (2006). Faktory rozhdayemosti [Fertility factors]. Moscow: TEIS.

Arutyunyan M.Yu. (1997). Gendernyye otnosheniya v sem'ye [Gender relations in the family]. In Materialy Pervoy Rossiyskoy letney shkoly po zhenskim i gendernym issledovaniyam «Valday-96» [Materials of the First Russian Summer School on Women's and Gender Studies "Valdai-96"] (pp. 136-141). MTsGI. (In Russ.).

Belyayeva L.A. (2004). Sotsial'nyy portret vozrastnykh kogort v postsovetskoy Rossii [Social portrait of age cohorts in post-Soviet Russia]. In Sotsiologicheskiye Issledovaniya [Sociological research], 10, 31-42.

Benjamin A., Crymble S.B. (2017). A Re-Imagination of the Transition to Adulthood. In A. Laros, T. Fuhr, E. W. Taylor (Eds.), Transformative Learning Meets Bildung (pp. 247-258). SensePublishers. URL: https://doi.org/10.1007/978-94-6300-797-9_20 
Billari F.C., Hagestad G.O., Liefbroer A.C., Spéder Z. (2005). The Timing of Life: The Organization of the Life Course in Europe. In The timing of life: The organisation of the life course in Europe. European Social Survey. URL:

http://www.europeansocialsurvey.org/docs/round3/questionnaire/ESS3_billari_proposal.pdf

Billari F.C., Liefbroer A.C. (2010). Towards a new pattern of transition to adulthood? Advances in Life Course Research, 15(2), 59-75.

Billari F.C., Hagestad G.O., Liefbroer A.C., Zsolt S. (2005). Question Module Design Team (ESS Round 3) Application Form: The Timing of Life: The Organization of the Life Course in Europe. URL:

http://www.europeansocialsurvey.org/docs/round3/questionnaire/ESS3_billari_proposal.pdf

Billari Francesco C., Liefbroer A.C. (2007). Should I Stay or Should I Go? The Impact of Age Norms on Leaving Home. Demography, 1, 181. URL: https://doi.org/10.2307/4137227

Blum A., Sebille P., Zakharov S.V. (2009). A divergent transition to adulthood in France and Russia: A cohort approach. Revue d'Etudes Comparatives Est-Ouest, 40(3-4), 123-152.

Buchmann M. (1989). The script of life in modern society: Entry into adulthood in a changing world. Chicago: University of Chicago Press.

Corijn M., Klijzing E. (2001). Transitions to adulthood in Europe. Springer. URL: http://dx.doi.org/10.1007/978-94-015-9717-3

Darskiy L.E., Il'ina I.P. (1990). Normalizatsiya brachnosti v SSSR [Normalization of marriage in the USSR]. In Demograficheskiye protsessy v SSSR [Demographic processes in the USSR], (pp. 6-27). Moscow: Nauka [Science].

Denisenko M.B., Dalla Zuanna Zh.-P. (2001). Seksual'noye povedeniye rossiyskoy molodezhi [Sexual behavior of Russian youth]. In Sotsiologicheskiye Issledovaniya [Sociological Research], 2, 83-87.

Dolgova A.A., Mitrofanova E.S. (2015). Otdeleniye ot roditeley v Rossii: Mezhpokolencheskiy aspect [Separation from Parents in Russia: An Intergenerational Aspect]. In Ekonomicheskaya Sotsiologiya [Economic Sociology]. URL: https://publications.hse.ru/articles/168019618

Erikson E.H. (1995). Identity: Youth and Crisis. New York: W. W. Norton \& Company.

Espy IV T.H., Mitrofanova E.S. (2017). Sequence Analysis of the Migration Biographies of Russians (SSRN Working Paper ID 3071733). Social Science Research Network.

Frejka T., Zakharov S. (2012). Comprehensive analyses of fertility trends in the Russian Federation during the past half century. Max Planck Institute for Demographic Research. Series "MPIDR Technical Report”. No. WP2012-027.

Gabriel F. (2013). Deconstructing Youth. Palgrave Macmillan UK. URL: https://doi.org/10.1057/9781137317520

Gauthier A.H. (2007). Becoming a Young Adult: An International Perspective on the Transitions to Adulthood. European Journal of Population, 23(3-4), 217-223.

URL: https://doi.org/10.1007/s10680-007-9130-х

Giddens A. (1994). Living in a post-traditional society. In Reflexive Modernization; Politics, Tradition and Aesthetics in the Modern Social Order (pp. 56-109). Cambridge, UK: Polity Press; Blackwell. 
Gimpel'son V.E., Zudina A.A. (2017). Demograficheskiye problemy rynka truda [Demographic problems of the labor market]. In Demoskop Weekly [Demoscope Weekly], 729-730. URL: http://www.demoscope.ru/weekly/2017/0729/tema01.php

Golod S.I. (2005). Chto bylo porokami, stalo nravami. Lektsii po sotsiologii seksual'nosti [What were vices became morals. Lectures on the Sociology of Sexuality]. Moscow: Ladomir.

Heinz W.R., Marshall V.W. (2003). Social dynamics of the life course: Transitions, institutions, and interrelations. New York: Aldine de Gruyter.

Horowitz A.D., Bromnick R.D. (2007). "Contestable Adulthood”: Variability and Disparity in Markers for Negotiating the Transition to Adulthood. Youth, Society, 39(2), 209-231. URL: https://doi.org/10.1177/0044118X06296692

Huinink J. (2013). De-Standardisation or Changing Life Course Patterns? Transition to Adulthood from a Demographic Perspective. In The Demography of Europe (pp. 99-118). Springer Netherlands. URL: https://doi.org/10.1007/978-90-481-8978-6_5

Ipatova A.A., Tyndik A.O. (2015). Reproduktivnyy vozrast: 30-letniy rubezh v predpochteniyakh i biografiyakh [Reproductive age: 30-year-old in preferences and biographies]. In Mir Rossii [World of Russia], 4, 123-148.

Kon I.S. (1997). Seksual'naya kul'tura v Rossii: Klubnichka na berezke [Sexual Culture in Russia: Strawberry on a Birch]. Moscow: OGI (United Humanitarian Publishing House).

Kon I.S. (2010). Tri v odnom: Seksual'naya, gendernaya i semeynaya revolyutsii [Three in one: Sexual, gender and family revolutions] In Demoskop Weekly [Demoscope Weekly], 447-448.

Konstantinovskiy D.L. (2008). Neravenstvo i obrazovaniye. Opyt sotsiologicheskikh issledovaniy zhiznennogo starta rossiyskoy molodezhi (1960-e gody-nachalo 2000-kh) [Inequality and education. The experience of sociological research on the life start of Russian youth (1960s - early 2000s)]. Moscow: Center for Social Forecasting.

Liefbroer A.C. (1999). From Youth to Adulthood: Understanding Changing Patterns of Family Formation from a Life Course Perspective. In Population Issues (pp. 53-85).

The Netherlands: Springer.

Lowe S.R., Dillon C.O., Rhodes J.E., Zwiebach L. (2013). Defining Adult Experiences: Perspectives of a Diverse Sample of Young Adults. Journal of Adolescent Research, 28(1), 31-68. URL: https://doi.org/10.1177/0743558411435854

Mitrofanova E.S. (2016). Russian Generations: Sequencing the Transition to Adulthood. In Proceedings of the International Conference on Sequence Analysis and Related Methods (LaCOSA II) (pp. 263-275). Lausanne: LaCOSA II. URL: https://publications.hse.ru/chapters/185791867

Mitrofanova E.S. (2019). Modeli vzrosleniya raznykh pokoleniy rossiyan [Maturation models of different generations of Russians]. In Demograficheskoye Obozreniye [Demographic Survey], 6(4), 53-82.

Mitrofanova E.S., Artamonova A.V. (2015). Posledovatel'nost' zhiznennykh sobytiy u rossiyskikh muzhchin, sluzhivshikh i ne sluzhivshikh $\mathrm{v}$ armii [The sequence of life events in Russian men who served and did not serve in the army]. In Demograficheskoye Obozreniye [Demographic Survey], 4, 5-36. URL: https://doi.org/10.17323/demreview.v2i4.1769

Popov A.A., Visser A.Ph., Ketting E. (1993). Contraceptive Knowledge, Attitudes, and Practice in Russia during the 1980s. Studies in Family Planning, 24(4), 227-235. URL: https://doi.org/10.2307/2939190 
Pressa R. (1966). Narodonaseleniye i ego izucheniye: Demograficheskiy analiz [Population and its Study: A Demographic Analysis]. Statistika [Statistics].

Puur A., Rahnu L., Maslauskaite A., Stankuniene V. (2012). Past and present patterns of family formation in Eastern Europe: Does Hajnal's delineation still matter? Filosofija Sociologija, 23(4), 256-265.

Puur A., Rahnu L., Maslauskaite A., Stankuniene V., Zakharov S. (2012). Transformation of Partnership Formation in Eastern Europe: The Legacy of the Past Demographic Divide. Journal of Comparative Family Studies, 43(3), 389-417.

Raveaud M. (2010). Becoming an Adult in Europe: A Socially Determined Experience. European Educational Research Journal, 9(3), 431-442. URL: https://doi.org/10.2304/eerj.2010.9.3.431

Remshmidt Kh. (1994). Podrostkovyy i yunosheskiy vozrast: Problemy stanovleniya lichnosti [Adolescence and Adolescence: Problems of Personality Formation]. Moscow: Mir [World]. URL: http://www.childpsy.ru/lib/books/id/8335.php

Rindfuss R.R. (1991). The Young Adult Years: Diversity, Structural Change, and Fertility. Demography, 28(4), 493.

Sem'ya i rozhdayemost': Osnovnyye rezul'taty vyborochnogo obsledovaniya. 2009 god [Family and Fertility: Main Results of a Sample Survey. Year 2009] (2010). Moscow: IITs "Statistika Rossii". [IIC "Statistics of Russia"].

Shoven J.B., Goda G.S. (2011). Adjusting Government Policies for Age Inflation. In Demography and the Economy (pp. 143-168). Chicago: University of Chicago Press. URL: https://doi.org/10.7208/chicago/9780226754758.003.0005

Sifman R.I. (1968). Intervaly mezhdu rozhdeniyami i mezhdu vstupleniyem v brak i pervym rozhdeniyem [Intervals between births and between marriage and first birth]. In Izucheniye vosproizvodstva naseleniya [Study of population reproduction], (pp. 107-133). Moscow: Nauka [Science].

Tol'ts M.S. (1974). Kharakteristika nekotorykh komponentov rozhdayemosti v bol'shom gorode [Characteristics of some components of fertility in a big city]. In Demograficheskiy analiz rozhdayemosti [Demographic analysis of fertility]. Valentey D.I. (Ed.) (pp. 45-55). Moscow: Statistika [Statistics].

Tol'ts M.S. (1977). Brachnost' naseleniya Rossii v kontse XIX - nachale XX v [Marriage rate of the population of Russia in the late XIX - early XX centuries]. In Brachnost', rozhdayemost', smertnost' $v$ Rossii $i$ v SSSR [Marriage, fertility, mortality in Russia and the USSR]. Vishnevskiy A.G. (Ed.) (pp. 138-153). Moscow: Statistika [Statistics].

Troitskaya I., Avdeyev A., Kapanadze E., Tret'yakova V. (2010). Sravnitel'nyy analiz kontratseptivnogo povedeniya: Frantsiya, Gruziya, Litva i Rossiya [Comparative analysis of contraceptive behavior: France, Georgia, Lithuania and Russia]. In Evolyutsiya sem 'i v Evrope: Vostok-Zapad [Family evolution in Europe: East-West]. Zakharov S.V., Prokof'yeva L.M., Sinyavskaya O.V. (Ed.) (pp. 266-304). Moscow: NISP.

Vikat A., Spéder Z., Beets G., Billari F.C., Bühler C., Désesquelles A., Fokkema T., Hoem J.M., MacDonald A., Neyer G. (2007). Generations and Gender Survey (GGS): Towards a better understanding of relationships and processes in the life course. Demographic Research, 17, $389-440$.

Vishnevskiy A.G., Kon I.S. (Ed.) (1979). Brachnost', rozhdayemost', sem'ya za tri veka [Marriage, fertility, family in three centuries]. Moscow: Statistika [Statistics] 
Vishnevskiy A.G., Tol'ts M.S. (1988). Evolyutsiya brachnosti i rozhdayemosti v sovetskiy period [Evolution of marriage and fertility in the Soviet period]. In Naseleniye SSSR za 70 let [Population of the USSR for 70 years], (pp. 75-114). Moscow: Nauka [Science].

Vishnevskiy A.G. (Ed.) (2006). Demograficheskaya modernizatsiya Rossii, 1900-2000 [Demographic modernization of Russia, 1900-2000]. Moscow: Novoe izdatel'stvo.

Vleioras G., Mantziou A. (2018). Social Role Transitions and Perceived Adulthood Status: Which Ones Matter for Whom? Emerging Adulthood, 6(3), 200-205. URL: https://doi.org/10.1177/2167696817722470

Zakharov S.V. (2006). Vozrastnaya model' braka [Age model of marriage]. In Otechestvennyye Zapiski [Domestic Notes], 4(31), 271-300.

Zakharov S.V. (2007). Transformatsiya brachno-partnerskikh otnosheniy v Rossii: "zolotoy vek" traditsionnogo braka blizitsya k zakatu? [Transformation of Marriage and Partnership Relations in Russia: Is the Golden Age of Traditional Marriage Coming to the End?]. In Roditeli i deti, muzhchiny i zhenshchiny v sem'ye i obshchestve. Vypusk 1 [Parents and children, men and women in the family and society. Issue 1]. T.M. Maleva, O.V. Sinyavskaya (Ed.) (pp. 75-127). Moscow: NISP.

Zakharov S.V. (2009). Tsennostno-normativnyye "raspisaniya" chelovecheskoy zhizni: Predstavleniya zhiteley raznykh stran o tom, kogda devushka stanovitsya vzrosloy [Valuable Normative "Schedules" of Human Life: Representations of Residents of Different Countries about When a Girl Becomes an Adult]. In Rossiya v Evrope. Po materialam mezhdunarodnogo proyekta "Evropeyskoye sotsial'noye issledovaniye" [Russia in Europe. Based on the materials of the international project "European Social Research"], (pp. 347379). Moscow: Academia.

Zakharov S.V. (2013). Rozhdayemost' i vosproizvodstvo naseleniya [Fertility and population reproduction]. In Naseleniye Rossii 2010-2011: Vosemnadtsatyy-devyatnadtsatyy ezhegodnyy demograficheskiy doklad [Population of Russia 2010-2011: Eighteenth to nineteenth annual demographic report], (pp.276-385). Moscow: HSE publishing house.

Zakharov S.V. (2018). Rozhdayemost' i planirovaniye sem'i v Rossii [Fertility and family planning in Russia]. In Naseleniye Rossii 2016: Dvadtsat' chetvertyy ezhegodnyy demograficheskiy doklad [Population of Russia 2016: Twenty-fourth annual demographic report], (pp. 186-259). Moscow: HSE publishing house.

Zdravomyslova O.M., Shurygina I.I. (2001). Vyzhit' ili preuspet': Predstavleniya starsheklassnikov o svoikh zhiznennykh shansakh [Survive or Succeed: High School Students' Perceptions in Life]. In Kto i kuda stremitsya vesti Rossiyu? Aktory makro-, mezo- $i$ mikrourovney sovremennogo transformatsionnogo protsessa [Who is seeking to lead Russia and where? Macro, meso- and microlevel actors of the modern transformation process], (pp. 366-374).

URL: http://ecsocman.hse.ru/data/250/679/1219/048.ZDRAVOMYSLOVA.pdf

Zdravomyslova E.A., Temkina A.A. (2004). Ot litsemeriya k ratsionalizatsii: Diskursivnaya transformatsii v sfere seksual'nykh otnosheniy [From Hypocrisy to Rationalization: Discursive Transformations in Sexual Relations]. In Gendernyye Issledovaniya [Gender Studies], 11, 176-186.

Zdravomyslova E.A., Temkina A.A. (2008). Istoriya i sovremennost': Gendernyy poryadok v Rossii [History and Present: Gender Order in Russia]. In Gender dlya "chaynikov" [Gender for dummies], (pp. 55-85). Moscow: Zven'ya. URL: http://med-books.info/psihologiyagendernaya/gender-dlya-chaynikov.html 